\title{
The Effect Of Social Media Marketing On Value Equity, Brand Equity And Relationship Equity On Young Entrepreneurs In Medan City
}

\author{
Bongsu Hutagalung \\ Dept. Of Management \\ Faculty Economy And Business \\ University of Sumatera Utara \\ Medan, Indonesia \\ rajabongsuh@yahoo.com
}

\author{
Alfifto \\ Dept. Of Management \\ Faculty Economy And Business \\ University of Sumatera Utara \\ Medan, Indonesia \\ alfifto.tanjung@gmail.com
}

\author{
Syafrizal Helmi Situmorang \\ Dept. Of Management \\ Faculty Economy And Business \\ University of Sumatera Utara \\ Medan, Indonesia \\ shelmi09@gmail.com
}

\begin{abstract}
Digital era has influenced varians business and marketing types. Social media has given big impact on marketer to promote their brands, covering worldwide marketing, increasing the sales and building the community compared to conventional media. The purpose of this research is to analyze the influence social media marketing on value equity, brand equity and relationship equity of young entrepreneurs in Medan City. This research used purposive sampling on 150 young entrepreneurs by using social media. Data was analyzed by regression linear. Data collection was made through questionnaires, observation and interview. Result showed that young entrepreneurs prefer instagram and facebook as the tools for promotion and women entrepreneur prefer instagram as well. Result also showed that social media marketing has positive on value equity, brand equity and relationship equity on young entrepreneurs in Medan City.
\end{abstract}

\section{Keywords-:social media, value equity, brand equity, relationship equity}

\section{Introduction}

Before 1990, there were few channel available where a company could communicate with a consumer: at an event, by fax, through direct mail, by telephone, on television, through the radio, on a billboard, or in a print magazine or newsletter. Now, there are literally hundreds of channels where consumers access content. The rise of Web 2.0 applications and the ability for users to generate content has changed the nature of online interactions, how customers learn and share about products and services, and how marketing is done [1]. Web 2.0 technologies make it easy for people to create and publish content, to share ideas, to vote on them, and to recommend things to others. Users have the opportunity to use web browser based user interfaces, such as, photos, video, text information, as well as to exchange with it, or to create groups based on interest into the specific materials. Social media allows for the users to place and perceive information of different type and form of publishing [2]

For businesses and entrepreneur, social media can be an inexpensive and instant publishing channel, Real-time listening market and customers, An informal, two-way communication channel between business and customers [3]. [4] have detailed five reasons for this power shift: No technology barriers, Talent availability, Content acceptance, Social Media and Google. Social media and their application to the field of marketing have had a significant impact on business structures, make a deep transformation models of the organizational and make change marketing dynamics the companies'[5]; [6]. The social media give the entrepreneurs a oppurtunity to gathering information, monitoring the opinion of users, involving the targeted audience in a dialogue about the products and services, improving brand awareness, atracting new consumers, forecasting consumer purchasing behaviour, building consumer loyalty, and increasing sales, [7]; [8]; [9]; [10].

[11] point out many business have integrated social media into their marketing plans; in order to they exploit an opportunity to contact end-users in a timely and direct way, at a relatively lower cost and higher level of efficiency than can be achieved with more traditional communication and marketing tools. This indicates, with social media, business can receive valuable information about customer, including customer selection, social effect and kinds of social interactions [12]. SMEs has a significant contribution to many development such as contribute to GDP, Reduce unemployment, create new job, innovation. Research by [13] 
SMEs have raised the standards of living for their families and also play an crucial task in contributing towards a stable and sustainable social and economic community environment. This research aim to look impact social media to customer value in youth entrepreneur Small business in Medan.

As we know, social media does have several potential benefits and key channel to advertise and sell products of small business. Social Media make closer to customers, simplify increased the revenue, reduction cost and efficiencies are the main to entrepreneur. But unfortunately, many entrepreneurs of small business can't use social media effectively for engagement to customer, increasing sales, brand awareness and loyalty [14]. According to [15] To successfully use the benefit of social media marketing, companies need to change experiences that make a real value in return for customers' time, attention, endorsement and data.

[16] suggest four foundation engagement model with customer collaboration in social media marketing such as consumption, curation, creation, and collaboration. The enggagement model of social media marketing can be combined to promote smart strategy, business-building processes in both marketing and operations. The combined acts of consumption, curation, creation, and collaboration carry consummer in the conversations around business from readers to talkers to co-creators. Interacting in social media gives entrepreneurs the ability to know and recognizes what's happening much faster than ever before, estimating the potential value of customer, because social media marketing gives the entrepreneur an idea of how much more can get from customer [17]. Business can gain more and more customer equity [18]. For entrepreneurs, customer equity is certain to be the most important determinant of the long-term value of business. Customer equity is combined marketing and business strategy for grow the value of the customer, at the heart of the business. Customer equity represents the total of the discounted lifetime values of all the firm customers [19]

Customer equity driven by value equity, brand equity and relationship equity [20]; [21]; [22]. From the aspect of relationship marketing, customer equity has two driving factors: brand equity and relationship equity. Customers decide to estabilish and maintain long-term relationship with the firm, which is driven by the value of the product and factor factor in purchase relationship [23]; [24]). Studied by [25] social media marketing have positive significant to value equity, brand equity and relationship equity.

[26] studied of 2,100 companies, while two-thirds of respondents were actively using social media, only $7 \%$ successfully integrated it into their marketing activities;most of companies were trying to understand the effect of social media on branding and searching for best practices to use it. The aim of this paper is to focus on the latter mean of building value equity, brand equity and relationship equtiy through social media marketing. Social media defined as the process that motivated entrepreneur to promote their websites, products, or services through online social channels and enter bigger community that may not have been available on traditional way. This research will propose a strategy to enhance customer equity trough social media marketing and the results will motivated youth entrepreneur create and manage customer equity and social media activity as well.

\section{Literature Review}

\section{A. Engagement model Socia Media Marketing}

[27] state social media are online applications, platforms and media which use to facilitate interactions, collaborations and sharing of content. According to [28], social media can have a huge impact on a brand's image and reputation. The different between socialmedia and traditional marketing is Traditional marketing involves creating a one-way message, crafted by the marketer. Social media a shaving a two-way conversation with your constituents. Engagement is the key to social media. Effective social media entails building a platform target markets, communicating and maintaining relationships. From a consumer's perspective, the use of ICT enhance these benefits such as efficiency, convenience, richer and participative information, a broader selection of products, competitive price, cost reduction, and product diversity [29], communicate more proactively, seek out others' opinions about specific products [30]. Social media engagement enhancesthe relative efficiency of business operation. According to [16] there are four foundation engagement model with customer collaboration in social media marketing such as consumption, curation, creation, and collaboration.

\section{B. Consumption}

The first of the foundational blocks in the process of building strong customer engagement is consumption. Consumption, as used in the context of social media, means downloading, reading, watching, or listening to digital content. Consumption is the basic starting point for nearly any online activity, and especially so for social activities. Consumption, as defined here, is a onedirectional action: You read, you download, you listen, etc. Consumption, by itself, does not drive social interaction. Maintaining the Integrity of the Specifications.

\section{Curation}

Curation is the act of sorting and filtering, rating, reviewing, commenting on, tagging, or otherwise describing content. Curation makes content more useful to others. Curation is an important social action in that it helps shape, prune, and generally increase the signal to-noise ratio within the community. Entrepeneurs must create something or 
finding material relevant to customer from a variety of sources, and sharing it strategically through social media channels. Curation isa very important action to encourage and teach customer to participate, creative, collaborative processes and become active members in community.

\section{Creation}

The Content creation requires thatcommunity members actually offer up something that they have made themselves. Entrepreneur must share what they are doing, talk (post) about the their business or product, and generally be recognized for their own contributions within the larger community. Reputation from entrepreneur is a key element in encouraging social interaction of the content created and shared by consumers. The combination of easy content publishing, curation, and visible reputation entrepreneurs are the cornerstones of a strong community.

\section{E. Collaboration}

Social media has led organizations to rethink their methods of managing and distributing information, and creating business value [31]. Now, Social media is one of the most powerful tools for marketing and branding. Social media offers entrepreneurs a chance to both lead and participate in discussions on a range of critical prevention issues, providing an easy way to connect with current and potential partners, funders and community stakeholders get noticed from target market, get content created and also generate WOM. It's this interactivity that makes the platforms so crucial to successful collaboration. Collaboration occurs naturally between members of the community when given the chance. Collaboration is so common in today's society. By connecting customers, business will get many benefits such as design new products or services, helping decision-making processes, solving problems, building consensus and customer relationship.

\section{F. Customer Equity}

The value a customer brings to a firm is not limited to the profit from each transaction but is the total profit the customer may provideover the duration of the relationship with the firm [32]. Thus, customers are seen as the intangible assets a firm should wisely acquire, maintain, and maximize just like other financial assets [33]. A strategy based on customer equity allows firms to trade off between customer value, brand equity, and customer relationship management. According to [19] There are three drivers of customer equity-value equity, brand equity, and relationship equity.

\section{G. Value Equity}

The keyword of the customer's relationship with the company is value. Value equity is defined as the customer's objective assessment of the utility of a brand, according to perceptions of what is given up for what is accepted. Three key levers that impact value equity: price, convenience and quality. Quality can be thought of as including the objective nonphysical and physical aspects of the product and service offering under the company's control. Price represents the aspects of "what is given up by the customer" that the company can impacted. Convenience relates to actions that help minimize the customer's costs, such as : search costs, time costs and efforts to do business with the company.

The are four benefit of Value equity (1) The most critical influencing customer perceptions of value. (2) Central for purchases with complex decision processes.(3) very important for most business-to-business purchases. (4) offers innovative products and services. Value equity is quite difficult to build in commodity markets, where products and competitors are often fungible.

\section{H. Brand Equity}

According to [34], brand is a complex phenomenon: "not only it is the actual product, but it's also the unique property of a specific owner and has been developed over time so as to embrace a set of attributes and values - both tangible and intangible - which meaningfully and appropriately differentiate products which are otherwise very similar. [35] stated Brands are the best at building images that make customers identify that specialty from among others . Value equity is driven by perceptions of objective aspects of a company's offerings, while brand equity is built through image and meaning. The brand serves three vital roles. First, it can serve as a reminder to customers about the firm's products and services. Second, it acts as a magnet to attract new customers to the firm. Finally, it can become the customer's emotional tie to the company.

[36] has provided definition of brand equity: A set of brand assets and its name and symbol, that added to or detracts from the value provided by a product or service to a company and/or to the company's customers. the equity of a brand depending on the number of people who purchase it regularly. The key actionable levels of brand equity are brand awareness, brand association, perceived value and brand loyalty According to [37] Brand equity is a customer's subjective and intangible assessment of the brand over and being on its value. Brand equity will be most important for low-involvement purchases with simple decision processes such as consumer goods. Brand equity also essential when the customer's use of the product is highly visible to others. the brand becomes an extension of the identity or image of customer. Brand equity will be vital when experiences associated with the product can be passed from generation or one individual to another. The role of the brand will be critical to make believed customer when they purchase credence goods, when it's difficult to evaluate quality prior 
to consumption. The value of strong brand identities such as a key tool for attracting new clients.

\section{Relationship Equity}

Every day, millions of people share their goings on by updating their status on social media. They impart thoughts and opinions by posting messages to their walls; leave personal notes and comments on those of others; communicate using the chat tool; exhibit photos of their activity; and share videos. [38]. For business, relationship will be critical and crucial. When firms have the opportunity to create learning relationships with customers or community, they will be loyal to business. It will be equty to business. Relationship equity is explained as the how the customer to stick with the brand, from the customer's spot and customer's assessments of the brand. The keystone of relationship equity, under the firm's control, loyalty programs, special recognition and treatment, affinity programs.

\section{Methodology}

Research used questionnaire (quantitative research) in order tomeasure. The study questionnaire benefited from the [16] in regard tothe statements used in the social media measurement. Questionnairecustomer equity, value quity, brand equity and relationship equity Benefited from the studies of [21]. Questionnaires weredelivered to 150 Respondents young entrepreneur were selected with convenience sampling.

\section{A. Data screening and analysis}

This research is an associative research that explains the influence between variables and directed to the relationship model of variation orientation variable social media marketing, value equity, brand equity, relationship equity and customer equity. The study is located at Medan city with the object of young entrepreneurs in Medan city. This study used nonprobability sampling with a sample number of 150 young entrepreneurs. The data collected were primary data from the questionnaires distributed in the sample using likert scale measurement, observation and interview with entrepreneurs. Secondary data from the literature and previous research for the needs of the study. Data processing begins with validity and reliability tests. Data analysis technique in this research using multiple regression analysis.

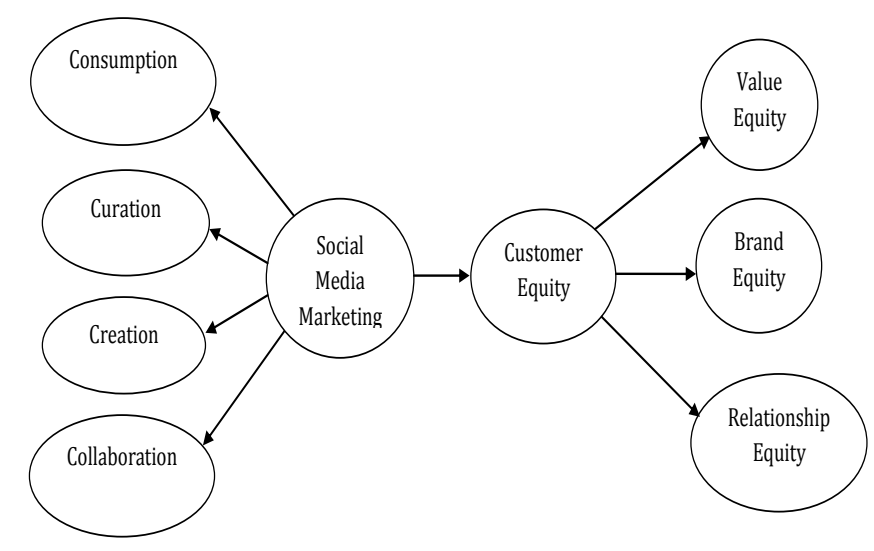

Figure 1. Conceptual model

IV. Finding and results

TABLE 1. RESPONDENT

\begin{tabular}{|c|c|c|c|c|c|}
\hline & Frequency & Percent & & Frequency & Percent \\
\hline \multicolumn{3}{|c|}{ Age } & \multicolumn{3}{|c|}{ Type of business } \\
\hline $18-20$ & 48 & 32.0 & Fashion & 37 & 24.7 \\
\hline $21-25$ & 68 & 45.3 & Service & 71 & 47.3 \\
\hline $26-30$ & 25 & 16.7 & Creative & 28 & 18.7 \\
\hline $31-35$ & 9 & 6.0 & Food & 8 & 5.3 \\
\hline Total & 150 & 100.0 & Furniture & 6 & 4.0 \\
\hline \multicolumn{3}{|c|}{$\begin{array}{c}\text { how long have you been in } \\
\text { business? }\end{array}$} & \multicolumn{3}{|c|}{ Social media used for business } \\
\hline $\begin{array}{l}<1 \\
\text { year }\end{array}$ & 24 & 16.0 & Facebook & 57 & 38.0 \\
\hline $\begin{array}{c}1-2 \\
\text { year }\end{array}$ & 47 & 31.3 & Instagram & 73 & 48.7 \\
\hline $\begin{array}{c}2-3 \\
\text { year }\end{array}$ & 76 & 50.7 & Path & 10 & 6.7 \\
\hline $\begin{array}{l}3< \\
\text { year }\end{array}$ & 3 & 2.0 & Line & 6 & 4.0 \\
\hline Total & 150 & 100.0 & $\mathrm{Bbm}$ & 2 & 1.3 \\
\hline \multicolumn{3}{|c|}{$\begin{array}{l}\text { how long have you used social } \\
\text { media? }\end{array}$} & Twitter & 2 & 1.3 \\
\hline $\begin{array}{c}6 \\
\text { month } \\
-1 \\
\text { year }\end{array}$ & 27 & 18.0 & Total & 150 & 100.0 \\
\hline $\begin{array}{c}1-2 \\
\text { year }\end{array}$ & 56 & 37.4 & \multicolumn{3}{|c|}{ Gender } \\
\hline $\begin{array}{c}2-3 \\
\text { year }\end{array}$ & 41 & 27.3 & Male & 67 & 44.7 \\
\hline$>3$ year & 26 & 17.3 & Female & 83 & 55.3 \\
\hline Total & 150 & 100.0 & Total & 150 & 100.0 \\
\hline
\end{tabular}

Form the table 1, it can be seen, the group age the average age of respondents is mostly young, the reason for choosing young entrepreneurs as respondents is young entrepreneurs are considered more easily adaptation and accept technological changes, especially the field of social media and the internet. According to Studied by [39] and [40]. Have found that younger managers are more inclined to adopt social media than are older managers. In addition to age, higher levels of education are believed toenhance the receptiveness of people to ideas and the ability to acquire 
information and reduceuncertainty. More recent studies of gender and social media find no gender differences in social media adoption [41] but rather differences in the type of social media outlets used by men and women. This research found respondent more likely to use Instagram and Facebook. Woman entrepreneurs most like using instagram as tool social media marketinghe template is designed so that author affiliations are not repeated each time for multiple authors of the same affiliation. Please keep your affiliations as succinct as possible (for example, do not differentiate among departments of the same organization). This template was designed for two affiliations.

TABLE. 2. DESCRIPTIVE VARIABLE

\begin{tabular}{|c|c|c|c|c|c|c|c|}
\hline \multicolumn{2}{|c|}{$\begin{array}{l}\text { Social Media } \\
\text { Marketing }\end{array}$} & \multicolumn{2}{|l|}{$\begin{array}{l}\text { Value } \\
\text { Equity }\end{array}$} & \multicolumn{2}{|l|}{$\begin{array}{l}\text { Brand } \\
\text { Equity }\end{array}$} & \multicolumn{2}{|c|}{$\begin{array}{l}\text { Relationship } \\
\text { Equity }\end{array}$} \\
\hline & Mean & & Mean & & Mean & & Mean \\
\hline $\begin{array}{l}\text { Consum } \\
\text { ption }\end{array}$ & 3.5 & Quality & 4.18 & $\begin{array}{l}\text { Brand } \\
\text { awareness }\end{array}$ & 4.27 & $\begin{array}{l}\text { Loyalty } \\
\text { Program } \\
\text { s }\end{array}$ & 3.79 \\
\hline $\begin{array}{l}\text { Curatio } \\
\mathrm{n}\end{array}$ & 3.45 & Price & 4.27 & $\begin{array}{l}\text { Perceived } \\
\text { quality }\end{array}$ & 3.88 & $\begin{array}{l}\text { Special } \\
\text { recogniti } \\
\text { on and } \\
\text { treatmen } \\
\text { t }\end{array}$ & 3.16 \\
\hline $\begin{array}{l}\text { Creatio } \\
n\end{array}$ & 3.18 & $\begin{array}{l}\text { Conveni } \\
\text { ence }\end{array}$ & 4.02 & $\begin{array}{l}\text { Brand } \\
\text { lmage }\end{array}$ & 3.66 & $\begin{array}{l}\text { Affinity } \\
\text { program }\end{array}$ & 3.56 \\
\hline $\begin{array}{l}\text { Collabo } \\
\text { ration }\end{array}$ & 2.99 & & & & & $\begin{array}{l}\text { Commu } \\
\text { nity- } \\
\text { building } \\
\text { program }\end{array}$ & 3.42 \\
\hline & & & & & & $\begin{array}{l}\text { Knowle } \\
\text { dge- } \\
\text { building } \\
\text { program }\end{array}$ & 4.51 \\
\hline
\end{tabular}

According to tabel 2, from variable social media marketing, mean of consumption and curation above 3.4 it means entrepreneurs agree that social media can increase customer activities. Customer like read and share information about product/service from business. Curation makes content more useful. Entrepreneurs have the opportunity to make their mark in front of their target customer by simply sharing their media content. Respondent agrees with the curation where the start of the interaction between the seller and the buyer through social media. From the table, it can be seen that social media marketing has not been used as a creation dan collaboration. community members just share and like photo. They not yet recommended the product through social media. Creation and collaboration are not functioning optimally in social media. In order to competitive business must used social media strategy. Now, many companies hire social media experts and consultants to create content and activities in social media environments so that the hearts and minds of the consumers are captured.

Value is the keystone of the customer's relationship with the firm. Also from the table, it can be seen, from dimmension of value equity, the price factor is more considered by consumers than quality or Convenience factors. From dimension of Brand equity, the brand awareness factormore considered by consumers than perceived quality or brand image from dimension of relationship equity, Knowledge-building and loyalty program more considered by consumers than other factors. Loyalty programs include actions that reward customers for specific behaviors with tangible benefits. Knowledgebuilding programs increase relationship between the customer and the firm, making the customer willing to repurchase, less switching to alternative product.

TABLE 3. RESULT

\begin{tabular}{|c|l|l|l|l|l|l|}
\hline \multirow{2}{*}{ From } & \multicolumn{1}{|c|}{ To } & $\begin{array}{c}\text { Unstandardized } \\
\text { Coefficients }\end{array}$ & $\mathrm{T}$ test & $\mathrm{R}$ & $\mathrm{R}^{2}$ & Hypothesis \\
\hline \multirow{3}{*}{$\begin{array}{l}\text { Social } \\
\text { media }\end{array}$} & $\begin{array}{l}\text { Value } \\
\text { equity }\end{array}$ & .353 & 10.269 & .645 & .416 & Supported \\
\cline { 2 - 7 } & $\begin{array}{l}\text { Brand } \\
\text { equity }\end{array}$ & .288 & 7.992 & .549 & .301 & Supported \\
\cline { 2 - 7 } & $\begin{array}{l}\text { Relationship } \\
\text { equity }\end{array}$ & .292 & 7.249 & .512 & .262 & Supported \\
\cline { 2 - 8 } & $\begin{array}{l}\text { Customer } \\
\text { equity }\end{array}$ & .973 & 15.066 & .778 & .605 & supported \\
\hline
\end{tabular}

From tabel 3, it can be seen, social media have positive impact and significant to value equity, brand equty and customer equity. It means if social media marketing increase then value equity, brand equty and customer equity tend to increase. Social media marketing also have more impact to variable value equity than to variable brand equity and customer equity. This indicates that if entrepreneurs give quality product with affordable price, so customer will be like to buy and if the customer feel comfort they will recommend the product. This is in line with the research [25] where as the social media marketing activities effectively enhance value equity by providing novel value to customer that traditional marketing do not used social media.

Social media have positive impact and significant to brand equity. This indicates that, as more and more entrepreneurs promote products or service through social media, it will grow the brand of the entrepreneur. Social media will generate brand awareness, so customers know about the product. According to the research of [42] Social media engagement has a significant impact on customerbased brand equity. Customer-based brand equity have four dimensions such as, brand awareness, brand image, perceived quality and brand loyalty. [43] also found in their research that social media marketing have positive impact to brand loyalty of the consumers, The results of the study showed that brand loyalty of the customers ispositively affected when the brand (1) offers advantageous campaigns, (2) offers relevant content, (3) offers popular contents.

Social media also have positive impact and significant to relationship equity, meaning that if the relationship of equity increases, then social media tend to increase. This indicates 
that entrepreneur must build connection to consumer. Consumers who are interested in the company's products will follow social media owned by the entrepreneur. This is in line with the research [28] that Social media marketing positively influenced to customer relationships and purchase intention. In social media when customer satisfied they wil recommend the product to other customers. When consumption, curation, creation and collaboration occur in social media, it can be said there is interaction between entrepreneurs and customers. it will turn customer into advocacy. In line of previous research [44] point out an effective use of time and resources, social media marketing give companies better communication grounds with the consumers to build brand loyalty beyond traditional methods. they have become more likely to talk about, recommend or purchase a company's products after they began engaged with the company on social media

Social media have positive impact and significant to customer equity, meaning of that if the customer of equity increases, then social media tend to increase. This indicates that,the more increase the entrepreneurs informing their product to social media, the more increase the customer equity, where there is a relationship that makes the customer becomes an asset in selling products through social media, especially with the ease of features provided by social media. This is in line with the research [21]; [45] based on the research, offer theoretical explanations for how parasocial relationships affect customer equity and customer lifetime value in social media contexts.

\section{CONCLUSIONS AND IMPLICATIONS}

\section{A. Conclusions}

The aim of this study was to understand the effect of social media marketing on customer equity such as relationship equity, brand equity and value equity from the perspective of the entrepreneurs. The results of the study are believed to put significant contribution to practice and literature since social media marketing can be defined as a new, but rapidly growing platform for building customer equity. As true for every nontraditional tool of marketing communications, social media marketing is eagerly explored, digged up, and utilized by the entrepreneurs. Therefore, research is timely and needed to ensure some direction in this quest. The results of this study shows that advantageous campaigns on social media marketing are the most significant drivers of customer equity. Social media marketing have positive impact dan significant to value equity, brand equity and relationship equity. Entrepreneurs thatwant to run effective social media marketing campaigns should take into consideration the customer equty. Entrepeneurs must offer to the consumers in their campaigns, what makes the consumers more likely to become loyal to their brands such as quality product with affordable price, convinience, membership. Social media marketing will generate brand awareness and brand image

\section{B. IMPLICATIONS}

This research still has limitations and require further research that is like using other measuring tools in viewing social media and also add other variables in subsequent research such as customer loyalty, customer satisfaction and customer experience, repurchase intention. Practically this research is expected to encourage young entrepreneurs to be more vigorous in marketing their products through the utilization of social media. through social media marketing, the company will receive benefits such as increased sales, reduce promotional costs, improve relationships between entrepreneurs with customers as well as between entrepreneurs and other entrepreneurs. for that entrepreneur must be able to create interesting social media content and encourage collaboration among fellow consumers

\section{References}

[1] Constantinides, E., \& Fountain, S. J. (2008). Web 2.0: Conceptual foundations and marketing issues. Journal of Direct, Data and Digital Marketing Practice, 9(3), 231-244.

[2] Grizanea, T and Jurgelaneb, I. (2016) Social Media Impact on Business Evaluation, Procedia Computer Science 104 ( 2017 ) 190 196

[3] Funk, T,(2011) Social Media Playbook for Business : Reaching Your Online Community with Twitter, Facebook, LinkedIn,and More, Praeger, California

[4] Joe Pulizzi, J.(2016) Content Inc, How entrepreneur use content to buid massive audiences and create radically successfull business, McGraw-Hill, New York

[5] Wu, C.W., (2016). The performance impact of social media in the chain store industry. Journal of Business Research.

[6] Kim, S. Koh, Y., Cha, J., Lee, S., 2015. Effects of social media on firm value for U.S. restaurant companies. International Journal of Hospitality Management 49 (1), 40-46.

[7] Castronovo, C., Huang, L., 2012. Social Media in an Alternative Marketing Communication Model. Journal of Marketing Development and Competitiveness 6 (1), 117-134.

[8] Dehghani, M., Tumer, M., 2015. A research on effectiveness of Facebook advertising on enhancing purchase intention of consumers. Computers in Human Behavior 49 (1), 597-600.

[9] Bianchi, C., Andrew, L., 2015. Investigating marketing managers' perspectives on social media in Chile. Journal of Business Research 68 (12), 2552-2559.

[10] Situmorang, S.H, Mulyono, H and Berampu, T.L. (2017) Peran dan manfaat social Media bagi usaha kecil, Proceding RIEE 6, USU, Medan

[11] Andreas, Kaplan M., Haenlein Michael 2010. "Users of the world, unite! The challenges and opportunities of social media". Business Horizons 53. (1). p. 61.

[12] Schniederjans, D., Cao, E.S., Schniederjans, M., 2013. Enhancing financial performance with social media: An impression management perspective. Decision Support Systems 55 (4), 911-918.

[13] Samujh, R. H. (2011). Micro-businesses need support: survival precedes sustainability. Corporate Governance, 11(1), 15-28.

[14] Michaelidou, N., Siamagka, N. T., \& Christodoulides, G. (2011). Usage, barriers and measurement of social media marketing: An exploratory investigation of small and medium B2B brands. Industrial Marketing Management, 40(7), 1153-1159. 
[15] Carolyn Heller Baird, Gautam Parasnis, (2011),"From social media to social customer relationshipmanagement", Strategy \& Leadership, Vol. 39 Iss: 5 pp. $30-37$

[16] Evans, D and McKee,J.(2010) Social Media Marketing: The Next Generation of Business Engagement, Wiley Publishing, Inc., Indianapolis, Indiana

[17] Villanueva, J. and Hanssens, D.M. (2007) Customer Equity : Measurement, Management and Research Opportunities, Publishers Inc, Boston

[18] Kim, J., Taylor, C. R., Kim, K. H., \& Lee, K. H. (2015). Measures of perceived sustainability. Journal of Global Scholars of Marketing Science, 25(2), 182-193

[19] Lemon K.N, Rust RT, Zeithaml VA. (2001) What drives customer equity? Mark Manage, 10(1):20-5.

[20] Hogan, J. E., Lemon, K. N., \& Rust, R. T. (2002). Customer equity management charting new directions for the future of marketing. Journal of Service Research, 5(1), 4-12.

[21] Rust, R. T., Lemon, K. N., \& Zeithaml, V. A. (2004). Return on marketing: Using customer equity to focus marketing strategy. Journal of Marketing, 68(1), 109-127.

[22] Zeithaml, V. A., Lemon, K. N., \& Rust, R. T. (2001). Driving customer equity: How customer lifetime value is reshaping corporate strategy.

[23] Chae, H., Ko, E., \& Han, J. (2015). How do customers' SNS participation activities impact on customer equity drivers and customer loyalty? Focus on the SNS services of a SPA brand. Journal of Global Scholars of Marketing Science, 25(2), 122-141.

[24] Teik, D. O. L. (2015). Enhancing the experience of needs satisfaction through service engagement: A case of commercial fitness centers in Malaysia. Journal of Global Scholars of Marketing Science, 25(2), 109-121.

[25] Kim A.J., and Ko, E. (2012) Do social media marketing activities enhance customer equity? An empirical study of luxury fashion brand, Journal of Business Research, 65 : 1480-1486

[26] Edelman, D. (2010). Branding in the digital age. Harvard Business Review, 88(12), 62-69

[27] Richter, A. and Koch, M. (2007). Social Transactions on Social Network Sites: Can Transaction Cost Theory contribute to a better understanding of Internet Social Networking? Bled, Slovenia.

[28] Kim A.J., and Ko, E. (2010) Impacts of luxury fashion brand's social media marketing on customer relationship and purchase intention. J Glob Fashion Mark 1(3):164-71.

[29] Bayo-Moriones, A., \& Lera-Lo 'pez, F. (2007). A firm-level analysis of determinants of ICTadoption in Spain. Technovation, 27(6/7), $352-366$.

[30] Berthon, P. R., Pitt, L. F., Plangger, K., \& Shapiro, D. (2012). Marketing meets Web 2.0, social media, and creative consumers: Implications for international marketing strategy.Business Horizons, 55(3), 261-271

[31] Tapscott, D., \& Williams, A.D. (2006). WIKINOMICS How Mass Collaboration Changes Everything. United States of America: Janson Text with Daily News.

[32] Kumar, V.And George, M. (2007) Measuring and maximizing customer equity: a critical analysis. J Acad Mark Sci 35:157-71.

[33] Blattberg, R., Getz, G., and Thomas J.S. (2011) Customer equity: building and managing relationships as valuable assets. Boston: Harvard Business School Presc

[34] Murphy, J. (1990), “Assessing the value of brands", Long Range Planning, Vol. 23 No. 3, pp. 23-9

[35] Kotler, Philip and Kevin Lane Keller, 2016. Marketing Managemen, 15th Edition, Pearson Education,Inc.

[36] Aaker, D.A. (1995), Managing Brand Equity. New York, The Free Press.

[37] Kim Changsu, et al. (2008). "An Empirical Study On The Integrated Framework of e- CRM in Online Shoping: Evaluating the Relationships Among Perceived value, Satisfaction and Trust Based on Customer Perspective". Journal of Elecreonis Commerce in Organization, Vol.6. No.3, p.1-19.

[38] Kietzmann, J., Hermkens, K., McCarthy, I. P., \& Silvestre, B. S. (2011). Social media? Get serious! Understanding the functional building blocks of social media. Business Horizons, 54(3), 241-251.

[39] Damanpour, F., \& Schneider, M. (2009). Characteristics of innovation and innovation adoption in public organizations: Assessing the role of managers. Journal of Public Administration Research and Theory, 19(3), 495-522.

[40] Wamba, S. F., \& Carter, L. (2014). Social media tools adoption and use by SMES: An empirical study. Journal of Organizational and End User Computing (JOEUC),26(2), 1-17.

[41] Anderson, M. (2015). Men catch up with women on overall social media use.Pew Research Center. August 28. 〈http://www.pewresearch.org/fact-tank/2015/08/28/men-catch-upwith-women-on-overall-social-media-use/>

[42] HardeepChahal, Anu Rani, (2017) "How trust moderates social media engagement and brand equity", Journal of Research in Interactive Marketing, Vol. 11 Issue: 3, pp.312-335

[43] Erdogmus, I.E, and Cicek, M (2012), The impact of social media marketing on brand loyalty, 8th International Strategic Management Conference, Procedia - Social and Behavioral Sciences 58 ( 2012 ) $1353-1360$

[44] Jackson, N. (2011) Infographic: Using Social Media to Build Brand Loyalty. Retrievedfrom:http://www.theatlantic.com.

[45] Vogel, V., Evanschitzky, H., \& Ramaseshan, B. (2008). Customer equity drivers and future sales. Journal of Marketing, 72, 98-108 (November).Tsimonis, G. and Dimitriadis, S. (2014), "Brand strategies in social media", Marketing Intelligence \& Planning, Vol. 32 No. 3, pp. 328-344.

[46] Pentina. I, Prybutok. V.R., Zhang. X, (2008). The role of virtual communities as shopping reference groups. Journal of Electronic Commerce Research, 9(2), 114-136.

[47] Dholakia, U.M., Bagozzi, R. and Pearo, L.K. (2004), "A social influence model of consumer participation in network- and smallgroup-based virtual communities", International Journal of Research in Marketing, Vol. 21 No. 3, pp. 241-263

[48] La Rose, R. and Eastin, M. (2004), "A social cognitive theory of internet uses and gratifications", Journal of Broadcasting and Electronic Media, Vol. 48 No. 3, pp. 358-377 